faced with the difficulties of reorganising an institution the funds of which were already dwindling owing to the monetary inflation, but with the secure conviction that only by the encouragement of research could German industry hope to regain its former position in the world. He played a leading part in the foundation of the Notgemieinschaft der deutschen Wissenschaft, and though some of his plans for the expansion of the Kaiser Wilhelm Institut had to be abandoned, it was not long before it was again in the forefront of research organisations. Meanwhile he himself was organising an attempt to pay the German War debt in gold won from sea-water, an attempt which failed yet yielded scientific results of importance.

The last years at Dahlem brought cares in plenty, but Haber's many industrial and administrative troubles were never allowed to interfere with the output of research from his private laboratory. The greater part of his work now was concerned with chain reactions and the mechanism of oxidation; perhaps his early association with Engler was responsible for this, and on this subject he worked with his assistants until the time of his death. He remained what he had always been, the ideal director of research, approachable, interested in everything, but above all the leader of the work of his Institute. His health was bad, but his industry enormous. Two honours he much appreciated were his election as an honorary fellow of the Chemical Society in 1931 ; and the award of the Rumford medal of the Royal Society in 1932.

The political situation in the spring of 1933 led to Haber's resignation. Almost all his staff and pupils were forced to look elsewhere for opportunities to continue their work, and he gave up his post rather than remain at Dahlem without them, in a country the political temper of which was so foreign to his own liberality of outlook. He spent himself unsparingly in helping his assistants and colleagues to find opportunities for continuing their work, and ultimately himself accepted an invitation of laboratory hospitality at Cambridge. $\mathrm{He}$ went to Cambridge in October and remained there to within a few days of his death. He had left for a short holiday on account of his health, intending to return to reside permanently at that University; but he died during the journey, at Basle, on January 29 , 1934.

Haber was equally outstanding as a man and as a chemist. His amazing knowledge of politics, history and economics, as well as of science and industry, and his superb gift of expression made him a fascinating conversationalist. It was always a joy to hear him tell a story, whether it was an anecdote of the War or one of his famous medieval romances. After a paper or a colloquium he showed his powers at their fullest. Never at a loss, whatever the subject, he would always open the discussion with some characteristic contribution of his own, in a way which showed his complete grasp of the subject. One of his outstanding characteristics was his pride in his work ; the final preparation of a paper was a work of infinite labour, but once it was completed he found it hard to accept any alteration in its conclusions; and though he was quick to acknowledge any mistake it was a source to him of acute mental discomfort. To his pupils he remained always courteous and affectionate, and to them his death is a great personal loss; but the world also is the poorer by the loss of one of its great benefactors and one of its great men.

O. H. W.-J.

\section{DR. F. L. KITCHIN, F.R.S}

Dr. Finlay Lorimer Kitchin was appointed palæontologist to the Geological Survey of Great Britain in 1905. He was attacked by sudden illness on January 17, 1934, and died in St. Thomas's Hospital on January 20. The post which he held for nearly thirty years was one which required an accurate and wide knowledge of the whole field of palæontological science, and he filled it with distinction and marked success. As a successor to such eminent men of science as Huxley, Salter, Etheridge, Shannon and Newton, he recognised the necessity of maintaining a high standard of performance and in no respect did his endeavours sink below the level of his predecessors.

Devoted to his subject, Kitchin was meticulously accurate, and at the same time he was able to co-operate freely not only with his official assistants but also with academic and other palæontologists who sought his advice. Being in charge of one of the largest collections of British fossils, on the curation and growth of which he had spent a large part of his working life, he acquired an experience of British stratigraphical palæontology which was probably unique. But he spared no efforts to secure the most accurate determinations, and he grudged neither time nor trouble, though often working on material which had less morphological value than stratigraphical interest. In this respect the value of his services to British geologists working in the field was unprecedented.

Kitchin's special sphere of work was in the province of Mesozoic palæontology. His earliest thesis, for the degree of $\mathrm{Ph} . \mathrm{D}$. at the University of Munich, where he studied under Zittel, was on Indian Jurassic Brachiopoda, and among his most important contributions to British palæontological stratigraphy were the two memoirs which he wrote with Dr. John Pringle on the Mesozoic rocks penetrated by borings in the coalfield of Kent. He also investigated the stratigraphy of the British Gault and contiguous formations, on which he wrote a number of useful papers. But he was very largely occupied by the preparation and editing of the palæontological chapters of memoirs on British geology, and the value of his services in this direction cannot be measured in terms of the amount of output which can now be attributed to his name. 
For thirty years Kitchin held a leading place in the esteem of all his fellow workers, and his thoroughness and critical ability gained the confidence not only of his colleagues but also of all stratigraphical palæontologists both in Britain and abroad.

Dr. Kitchin was born in Whitehaven in 1870 and educated at St. Bees School and at St. John's College, Cambridge. After graduating at Cambridge he studied at Munich for several years. For a short period he worked unofficially at the British Museum, and in 1898 he joined the Geological Survey as an assistant to E. T. Newton. He became palæontologist in 1905 . He was a vice-president of the Palæontographical Society and a fellow of the Royal Society. He took the degree of Sc.D. at Cambridge in 1923. For many years he had served on the council of the Geological Society, which in 1934 awarded to him the Lyell Medal, an honour which he did not live to receive.

Dr. Kitchin had a very wide circle of friends who were attracted to him by his obvious sincerity and great willingness to help all earnest scientific workers. Of a retiring disposition, he was passionately fond of music and was himself no mean executant. He was twice married and leaves a widow, two sons and one daughter. On January 23, at Golder's Green, a large assembly of colleagues and scientific friends paid their last respects to a man of science, who was not only personally beloved, but had also taken an important part in the scientific activities of British palæontologists for nearly forty years.

J. S. F.

\section{Mr. Douglas W. Freshifeld, D.c.t.}

Mr. Dougras Freshfield, who died in his eighty-ninth year on February 9, was prominent as a promoter of the serious study of geography for more than fifty years. As an Eton boy he made several ascents in the Alps and his love of mountains grew with his growth. He was recognised as one of the greatest mountaineers of the Alpine Club; but his attitude was that of an explorer and student of mountains rather than that of a sportsman, keen on records of first ascents. He broke new ground in the Alps, the Caucasus and the Himalayas, and in his sixtieth year he started from Mombasa with the intention of making an ascent of Mt. Ruwenzori, and he reached $12,000 \mathrm{ft}$. before turning. He wrote many books of much cnarm; the two largest, "The Exploration of the Central Caucasus" (1896) and "Round Kangchenjunga" (1903), are permanent works of great value, masterpieces of the literature of travel and illustrated with superb photographs. His biography of the great Swiss mountaineer and man of science, H. B. de Saussure (1920), was recognised as a classic.

Mr. Freshfield was admitted a fellow of the Royal Geographical Society in 1869 by Sir Roderick Murchison, and became a member of the council in 1878. Except for the ten years following 1894, when he withdrew from the affairs of the
Society as a protest against certain retrograde tendencies, he served throughout his life as honorary secretary, vice-president, president (during the difficult War years 1914-17) and finally in the high office of trustee. He was always a force for progress and in continuous opposition to the tyranny of old tradition. His reserved nature and fine taste led him to shun publicity; but when the occasion demanded it, as in the fight for the admission of ladies as fellows in 1893, he took a prominent part and conducted controversy with cogent argument and caustic wit.

Freshfield made no pretence of being a seientifie man ; but he preached and practised the doctrine of acute observation and accurate description. $\mathrm{He}$ rendered noble service to the science of geography by his encouragement of research and of higher education. In 1884, recognising the futility of the Society's scheme of encouraging geographical education by offering prizes to the public schools, he initiated an inquiry into the state of geographical teaching on the Continent and secured the appointment of the late Sir John Keltie for that purpose. The resulting report started the modern revival in British geography. Mr. Freshfield continued to urge that the best way to improve school teaching of the subject was to secure the recognition of the high cultural value of geography by the universities. Starting with his own University of Oxford, he secured the appointment of Sir Halford. Mackinder as reader in geography in 1887 when there was no chair of geography in any British university, and he lived to see professors and honours schools of geography in practically every one as the direct result of his initiative.

For thirteen years Mr. Freshfield acted as president of the Geographical Association, the aetivity of which in its special province of education he watched over with an interest only exceeded by his devotion to the work of the Royal Geographical Society and of the Alpine Club.

Freshfield's life was a fine illustration of the tradition of service which has led so many men of wealth and culture in England to toil for great ideals as strenuously as most men have to work for their living.

Hugh Robert Mill.

We regret to announce the following deaths:

Mr. E. G. B. Meade-Waldo, an original member of the Society for the Protection of the Fauna of the Empire, on February 24, aged seventy-nine years.

Dr. F. C. Purser, president of the Royal College of Physicians of Ireland and professor of medicine in the University of Dublin, on February 28.

Mr. William Barlow, F.R.S., known for his early work on the relation of crystal structure to chemical composition, on February 28, aged eightyeight years.

Prof. S. F. Oldenburg, for twenty-five years permanent secretary of the Russian Academy of Sciences, on February 28, aged seventy years. 